\title{
The Effect of Starvation on the Biochemical Composition of the Digestive Gland, the Gonads and the Adductor Muscle of the Scallop Flexopecten glaber
}

\author{
Khaoula Telahigue $^{1 *}$, Tarek Hajji ${ }^{1,2}$, Imen Rabeh ${ }^{1}$, M’hamed El Cafsi $^{1}$ \\ ${ }^{1}$ Research Unit of Physiology and Aquatic Environment, Faculty of Sciences of Tunis, University of Tunis El Manar, Tunis, Tunisia; \\ ${ }^{2}$ High Institute of Biotechnology of Sidi Thabet, University of Manouba, Ariana, Tunisia. \\ Email: ${ }^{*} \mathrm{k}$ telahigue@yahoo.fr \\ Received February $13^{\text {th }}, 2013$; revised March $13^{\text {th }}, 2013$; accepted March $20^{\text {th }}, 2013$ \\ Copyright (C) 2013 Khaoula Telahigue et al. This is an open access article distributed under the Creative Commons Attribution Li- \\ cense, which permits unrestricted use, distribution, and reproduction in any medium, provided the original work is properly cited.
}

\begin{abstract}
The effects of the starvation trial on the biochemical composition and the fatty acid dynamics in the triacylglycerol fraction of the digestive gland, gonads and adductor muscle of the scallop Flexopecten glaber were assessed. Results show that three weeks of food deprivation induce depletion of carbohydrates and a significant decrease in proteins and lipids. The noteworthy patterns recorded for the various classes of lipids were the increase of the amount of phosphatidylethanolamine against a strong decline of mono-diacylglycerols, triacylglycerol and phosphatidylserine classes in gonads. These results reflect the ability of Flexopecten glaber to remodel endogenous lipid classes in order to avoid the gonads deterioration. In the starved specimens, severe declines of the $n-3$ polyunsaturated fatty acid group were recorded in the triacylglycerol fraction of digestive gland and adductor muscle against the increase of this group in gonads. These results confirm the role of triacylglycerol as a polyunsaturated fatty acids reservoir and pointed out to their mobilization from storage organs to the developing gonads during the food shortage trial. Examination of fatty acid data revealed that food deprivation lead Flexopecten glaber to invest in saving and accumulation of highly unsaturated fatty acids in gonads. This applies mainly to the arachidonic acid (20:4n-6) and the docosahexaenoic acid (22:6n-3).
\end{abstract}

Keywords: Starvation; Scallop; Chemical Composition; Organs; Fatty Acid

\section{Introduction}

Bivalve mollusks experience nutritive stress, particularly under critical environment conditions and during the purification process for the consumed species [1,2]. Under stressful conditions, bivalves' survival depends on their metabolic reserves $[3,4]$. The relative contribution made by lipids, carbohydrates and proteins towards the utilization of energy reserves during starvation depends on the species and their stage of development $[5,6]$. According to many authors, the digestive gland and the adductor muscle represent the principal energy storage organs in pectinids [7-10]. Under a period of high energy demands, a transfer of metabolites from the digestive gland and the adductor muscle to the gonad was described in different scallop species $[4,9]$.

The scallop Flexopecten glaber is endemic Mediterranean species [11]. In Tunisia, this bivalve occurs in the

"Corresponding author. lagoon of Bizerte. The relatively low density of this specie in its natural habitat and its interesting nutritional values allowed us to consider $F$. glaber as a potential species for aquaculture [12]. In the case of bivalves, differences in the response to food availability may be of a great interest when considering the possibility of developing their culture [13].

The goals of this study is to gain information regarding the effects of nutritive stress on the biochemical composition and the fatty acid dynamics in lipid classes of the $F$. glaber digestive gland, gonads and muscle. It has also allowed to assess the relative importance of different metabolites and the strategy adopted by F. glaber to modulate its endogenous metabolic reserves to overcome the starvation trial.

\section{Material and Methods}

\subsection{Experimental Design and Animal Sampling}

A total of 96 wild adult Flexopecten glaber individuals 
of mean shell height $43 \pm 3 \mathrm{~mm}$ were collected by scuba diving from the Bizerte lagoon in the North east of Tunisia (longitude $9^{\circ} 48^{\prime} \mathrm{E}-9^{\circ} 56^{\prime} \mathrm{E}$ and latitude $37^{\circ} 08^{\prime} \mathrm{N}$ $37^{\circ} 14^{\prime} \mathrm{N}$ ) in the spring season. Thirty six specimens were sacrificed upon arrival to the laboratory and considered as initial condition or " $\mathrm{T}_{0}$ " (time zero) group. The other specimens were divided into equal groups and placed in three tanks (20 individuals per tank). Each tank contained $70 \mathrm{~L}$ of filtered and UV-treated seawater maintained at constant temperature $\left(15^{\circ} \mathrm{C}\right)$ and salinity $(35 \mathrm{psu})$. A photoperiod of 12-h light/12-h dark was sustained over the duration of the experiment.

During 3 weeks, samples were maintained unfed. A gentile aeration was applied in tanks to ensure an adequate supply of oxygen. Water was continuously filtrated and changed twice per week.

\subsection{Chemical Analysis}

\subsubsection{Gross Chemical Composition}

Total lipids were extracted according to the method of Folch et al., [14] with the solvent mixture chloroformmethanol $(2: 1, \mathrm{v} / \mathrm{v})$ containing $0.01 \%$ buthylatedhydroxy toluene (BHT) as an antioxidant. Carbohydrate and protein contents were colorimetrically quantified as described by Dubois et al., [15] and Lowry et al., [16] respectively.

\subsubsection{Lipid Classes' Separation}

Lipid classes were separated using thin-layer chromatography (TLC) with one dimensional double development as described in Olsen and Henderson [17]. Doses of $500 \mu \mathrm{l}$ of lipid extracts were separated on plates $(20 \times 20$ $\mathrm{cm}$, silica gel 60, Merck, Germany) using hexane: diethyl ether: glacial acetic acid (80:20:2, v/v) as developing solvent for neutral lipids and methyl acetate: isopropanol: chloroform: methanol: $0.25 \% \mathrm{KCl}(25: 25: 25: 10: 9, \mathrm{v} / \mathrm{v})$ as developing solvent for polar fraction. Lipid classes were visualized under UV light after spraying with $0.1 \%$ 2'-7'dichloro-fluorescein in absolute methanol.

\subsubsection{Analysis of Fatty Acids}

After evaporation to dryness, lipid extracts and fractions were trans-esterified according to the method of Cecchi et al., [18]. Methyl nonadecanoate 19:0 (Sigma), which didn't exist in our samples, was added as internal standard. Separation of FAMEs was carried out on a HP 6890 gas chromatograph with a split/splitless injector equipped with a flame ionization detector at $275^{\circ} \mathrm{C}$, and a $30 \mathrm{~m}$ HP Innowax capillary column with an internal diameter of $250 \mu \mathrm{m}$ and a film thickness of $0.25 \mu \mathrm{m}$. Injector temperature was held at $250^{\circ} \mathrm{C}$. The oven was programmed to rise from $50^{\circ} \mathrm{C}$ to $180^{\circ} \mathrm{C}$ at a rate of $4^{\circ} \mathrm{C} / \mathrm{min}$, from $180^{\circ} \mathrm{C}$ to $220^{\circ} \mathrm{C}$ at $1.33^{\circ} \mathrm{C} / \mathrm{min}$ and to stabilize at $220^{\circ} \mathrm{C}$ for 7 minutes. Nitrogen was the carrier gas. Identification of FAMEs was based on the comparison of their retention times with those of a mixture of methyl esters (SUPELCO PUFA-3). Fatty acid peaks were integrated and analyzed using the HP chemstation software.

\subsection{Statistical Analysis}

To assess significant differences between means, data was analyzed using the software R Version 2.1.2.1. according to the One Way Analysis of Variance method (ANOVA) method. In this respect, Duncan test was applied and differences were considered significant when $\mathrm{p}$ $<0.05$.

\section{Results}

\subsection{Gross Chemical Composition}

Data related to the effects of food deprivation on the biochemical composition of the digestive gland, the gonads and the adductor muscle of $F$. glaber are presented in Table 1. We noticed that in control individuals (initial), lipids were the major biochemical components in the digestive gland and gonads. Glycogen is mainly found in adductor muscle reaching $29.5 \mathrm{mgg}^{-1} \mathrm{ww}$. During the fasting trial, up to $60 \%$ of proteins were mobilized in the studied organs. The highest loss of protein

Table 1. The effect of the duration of food deprivation on the biochemical composition, proportions of neutral and polar lipids (percentage of total lipid), in the digestive gland, the gonads and the adductor muscle of Flexopecten glaber.

\begin{tabular}{|c|c|c|c|c|c|c|}
\hline & \multicolumn{2}{|c|}{ Digestive gland } & \multicolumn{2}{|c|}{ Gonads } & \multicolumn{2}{|c|}{ Muscle } \\
\hline & Initial & Unfed & Initial & Unfed & Initial & Unfed \\
\hline Proteins $\left(\mathrm{mgg}^{-1} \mathrm{ww}\right)$ & $13.7 \pm 0.5$ & $3.8 \pm 0.6$ & $9.5 \pm 1.2$ & $3.6 \pm 0.2$ & $10.7 \pm 0.2$ & $4.2 \pm 0.2$ \\
\hline Glycogen $\left(\mathrm{mgg}^{-1} \mathrm{ww}\right)$ & $3.6 \pm 0.1$ & $0.4 \pm 0.1$ & $4.0 \pm 0.7$ & $0.1 \pm 0.0$ & $29.5 \pm 0.8$ & $0.1 \pm 0.0$ \\
\hline Lipids ( $\left.\mathrm{mgg}^{-1} \mathrm{ww}\right)$ & $59.5 \pm 1.1$ & $19.1 \pm 0.8$ & $48.0 \pm 0.5$ & $22.9 \pm 0.6$ & $28.2 \pm 0.9$ & $3.9 \pm 0.9$ \\
\hline Neutral lipids (\%) & $91.5 \pm 2.7$ & $88.7 \pm 0.8$ & $71.9 \pm 2.6$ & $67.7 \pm 1.4$ & $16.1 \pm 0.2$ & $35.5 \pm 1.5$ \\
\hline Polar lipids (\%) & $8.5 \pm 0.5$ & $11.3 \pm 1.0$ & $28.1 \pm 0.2$ & $32.3 \pm 1.2$ & $83.9 \pm 0.9$ & $64.5 \pm 0.7$ \\
\hline
\end{tabular}

Results are mean \pm standard deviation of triplicate analysis $(n=12)$ except for neutral and polar lipids $(n=6)$. 
was recorded in the digestive gland with $72 \%$ of the initial amount. Concerning glycogen, we noted that this compound dropped to a complete depletion after 21 days in different examined tissues.

As to lipids, results show that $86 \%$ of the adductor muscle reserves of these compounds were depleted after 3 weeks of food shortage against $68 \%$ and $52 \%$ in digestive gland and gonads, respectively.

Results reported in Table 1 show that the lipids of the digestive gland and the gonads of F. glaber (initial) were dominated by the neutral fraction exceeding $90 \%$ and $70 \%$ respectively. However, in the adductor muscle, the polar lipids were the major compounds with $83.9 \%$ of total lipids.

Under food deprivation, we noted a decrease of the neutral lipids against an increase of the polar ones in the digestive gland and the gonads.

\subsection{Lipid Classes}

The content of the various lipid classes in studied organs before and after starvation trial is shown in Figure 1. Results demonstrate that phosphatidylcholine (PC) constitute the principal polar lipid fraction in the digestive gland (Figure 1(a)) and the adductor muscle (Figure 1(e)) of F. glaber. Whereas the gonad's polar lipids were dominated by PC and phosphatidylserine (PS) (Figure 1(c)). The neutral lipids of different organs (Figures 1(b), (d) and (f)) consisted mainly of cholesterol ester (Chol. E).

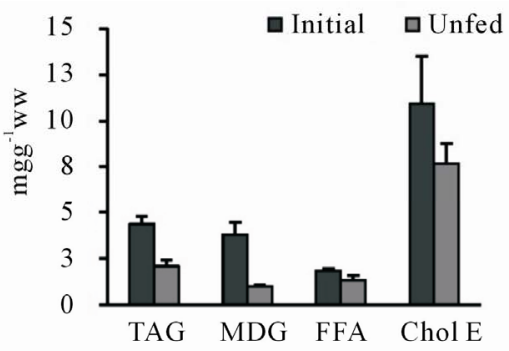

(b)

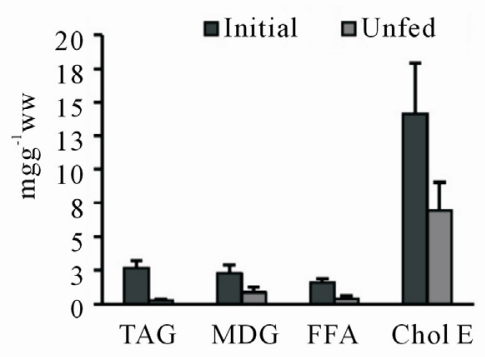

(d)

Gonads

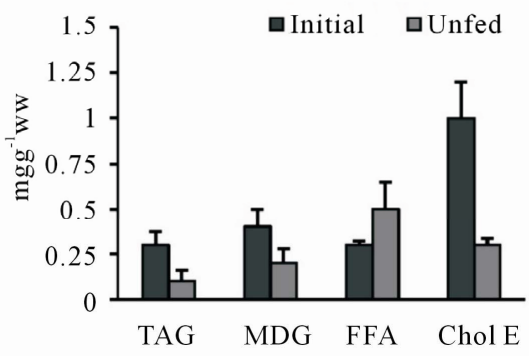

(f)

Adductor muscle

Figure 1. Impacts of starvation on polar and neutral lipid classes' content (expressed in $\mathrm{mg} / \mathrm{g}$ of wet weight) of digestive gland ((a) and (b)) gonads ((c) and (d)), and adductor muscle ((e) and (f)) of Flexopecten glaber. PC (phosphatidylcholine), PE (phosphatidylethanolamine), PS (phosphatidylserine), PI (phosphatidylinositol), TAG (triacylglycerol), MDG (mono-diacylglycerols), FFA (free fatty acids), Chol E (cholesterol ester). 
In the digestive gland, phosphatidylserine (PS) and phosphatidylinositol (PI) fractions remain at very low concentrations compared to the initial condition after 3 weeks of starvation. Nevertheless, The PC and phosphatidylethanolamine (PE) fractions show insignificant variations $(p>0.05)$. In the neutral fraction, we noted a significant decrease of mono-diacylglycerols (MDG) and Triacylglycerol (TAG) concentrations $(\mathrm{p}<0.05)$.

In the gonad's polar lipids (Figure 1(c)), the fasting trial induced a strong significant decline of PS and PC fractions against an increase in PE content $(\mathrm{p}<0.05)$. However, in the neutral lipids (Figure 1(d)), food deprivation led to drastic reduction $(p<0.05)$ in the contents of different fractions, mainly TAG and free fatty acids (FFA) as compared to those recorded at $\mathrm{T}_{0}$.

In the adductor muscle, starvation induced a significant decrease in different lipid classes at both polar (Figure 1(e)) and neutral (Figure 1(f)) fractions except for the FFA fraction which shows a significant increase $(\mathrm{p}<0.05)$.

\subsection{Fatty Acids Compositions}

TAG fatty acids compositions in the digestive gland, the gonads and the adductor muscle of $F$. glaber before and after the fasting trial are reported in Table 2.

In the digestive gland, the TAG fraction of the control specimens was dominated by the saturated fatty acids (SAFAs) group, which represents $50.1 \%$ of the total fatty acids. Among this group, the major fatty acids are the $14: 0$, the $16: 0$ (16.9\% and $19.8 \%$, respectively) and, at lesser level, the 18:0 (9.3\%). The main unsaturated fatty acids, represented in terms of percentage, were as follows: monounsaturated (MUFA) 16:1n-7 (9.5\%) and 20:1n-9 (5.1\%); polyunsaturated (PUFA) 20:5n-3 (6.2\%) and 22:6n-3 (9.8\%). The most abundant (n-6) fatty acids were the $18: 2 n-6(1.6 \%)$ and the $20: 4 n-6(2.2 \%)$.Under fasting, the most severe declines occurred in the 14:0; $16: 1 \mathrm{n}-7 ; 20: 5 n-3$ and $22: 6 \mathrm{n}-3$. Nevertheless, starvation has led to a significant increase in the 18:0 (from 9.3 to $34.0 \%$ ) and the $18: 2 \mathrm{n}-6$ (from $1.6 \%$ to $5.8 \%$ ). A decrease in n-3 PUFAs was noticed with a simultaneous increase in the $\mathrm{n}-6$ ones.

In the gonads, TAG's saturated fatty acids, mainly represented by $16: 0$ and 18:0 were significantly affected by the diet shortage $(p<0.05)$. The sum of SFA declined from $64.9 \%$ to $57.1 \%$. Among the MUFA group, starvation induced an elevation of the n-7 series fatty acids $(p<$ 0.05 ) mainly the $20: 1 \mathrm{n}-7$ (from $0.7 \%$ to $4.3 \%$ ).

In PUFA group, after 3 weeks of food deprivation, we recorded an increase in the percentages of the following fatty acids: 16:2, 16:3, 18:2n-6 and 22:6n-3. On the other hand, a significant decline in the proportions of the $18: 4 n$
$-3,20: 5 n-3$ and the $22: 3 n-3$ was recorded. The amount of the $n-3$ and the $n-6$ PUFAs groups remained invariable ( $p$ $>0.05$ ) in the gonads of the starved specimens.

In the adductor muscle, the TAG fraction of the unfed scallop was characterised by a high percentage of SFAs $(88.8 \%)$ in comparison with the initial group (59.7\%) (p $<0.05$ ). The main constituent of this group were C16:0 and C18:0. Proportions of these two SFAs had significantly increased $(p<0.05)$ when compared to their initial values (from $21.4 \%$ to $29.7 \%$ and from $30.6 \%$ to $54.5 \%$, respectively). Concerning the MUFA, starvation yielded a drastic drop of this group (from $21.9 \%$ to $6.6 \%$ ). The main fatty acids that were observed to decline in MUFA with respect to those of $T_{0}$ were $18: 1 n-9$ and 20:1n-9. Same trends were recorded in the different fatty acids belonging to the PUFAs group. Hence, lower content of the sum of PUFA including both n- 6 and n-3 series was recorded $(\mathrm{p}<0.05)$.

\section{Discussion}

The accumulation and depletion of stored reserves of Mollusca dependent mainly on the environmental influences as well as on metabolic activities, and the quantity and nutritional value of the food supply $[19,20]$. The usual response to nutritive stress is an increase or a decrease in metabolic rate according to whether food is present or not [13]. In this study, the effect of starvation on the scallop F. glaber shows a significant reduction in the levels of different metabolites (carbohydrates, proteins and lipids) in the digestive gland, the gonads and the adductor muscle. The components that are utilized to the largest extent are carbohydrates particularly in the adductor muscle. This compound dropped drasticcally to a complete depletion after the 21 days of starvation. We conclude that in F. glaber, carbohydrates are used in greater proportion than proteins and lipids. Similar results were recorded in the abalone Haliotis kamtschatkana [21], the clams Ruditapes decussatus and Venerupis pullastra [13] and the oyster Crassostrea gigas [22]. These authors have demonstrated that mollusks rely on glycogen as the main source of energy during fasting.

Our results have also shown that the adductor muscle is the main organ that is involved in glycogen storage in F. glaber. In fact, it has long been recognized that glycogen is the main energy reserve in juvenile and adult bivalves [23]. This metabolite is used as an energy reserve under adverse environmental conditions [24]. More recent studies have also confirmed the preferential use of carbohydrates as an energy source for bivalve molluscs in critical conditions $[21,22,25]$. According to Lane [26], the preferential utilization of glycogen in proportion to 
Table 2. Fatty acid composition of the triacylglycerol (TAG) of digestive gland, gonads and adductor muscle of Flexopecten glaber before and after the starvation trial.

\begin{tabular}{|c|c|c|c|c|c|c|}
\hline \multirow[b]{2}{*}{ Fatty acid } & \multicolumn{2}{|c|}{ Digestive gland } & \multicolumn{2}{|c|}{ Gonads } & \multicolumn{2}{|c|}{ Muscle } \\
\hline & Initial & Unfed & Initial & Unfed & Initial & Unfed \\
\hline $14: 0$ & $16.9^{\mathrm{a}} \pm 1.1$ & $3.4^{\mathrm{b}} \pm 0.4$ & $4.4^{\mathrm{a}} \pm 1.2$ & $3.5^{\mathrm{a}} \pm 0.6$ & $2.2^{\mathrm{a}} \pm 1.3$ & $1.7^{\mathrm{a}} \pm 0.7$ \\
\hline $15: 0$ & $0.5^{\mathrm{a}} \pm 0.1$ & $1.2^{\mathrm{b}} \pm 0.1$ & $5.7^{\mathrm{a}} \pm 0.6$ & $3.4^{\mathrm{b}} \pm 1.3$ & $0.6^{\mathrm{a}} \pm 0.2$ & $0.3^{\mathrm{a}} \pm 0.0$ \\
\hline $16: 0$ & $19.8^{\mathrm{a}} \pm 0.3$ & $16.9^{\mathrm{b}} \pm 2.0$ & $23.6^{\mathrm{a}} \pm 0.9$ & $20.2^{\mathrm{a}} \pm 0.9$ & $21.4^{\mathrm{a}} \pm 0.9$ & $29.7^{\mathrm{b}} \pm 1.9$ \\
\hline $17: 0$ & $2.1^{\mathrm{a}} \pm 0.1$ & $5.3^{b} \pm 0.9$ & $1.3^{\mathrm{a}} \pm 0.1$ & $2.2^{\mathrm{a}} \pm 1.0$ & $2.6^{\mathrm{a}} \pm 0.6$ & $2.3^{\mathrm{a}} \pm 1.1$ \\
\hline $18: 0$ & $9.3^{\mathrm{a}} \pm 0.9$ & $34.0^{\mathrm{b}} \pm 1.2$ & $26.3^{\mathrm{a}} \pm 2.1$ & $24.4^{\mathrm{a}} \pm 2.1$ & $30.6^{\mathrm{a}} \pm 3.0$ & $54.5^{\mathrm{b}} \pm 0.9$ \\
\hline $20: 0$ & $1.4^{\mathrm{a}} \pm 0.3$ & $0.4^{\mathrm{b}} \pm 0.1$ & $3.1^{\mathrm{a}} \pm 0.3$ & $3.0^{\mathrm{a}} \pm 0.2$ & $0.7^{\mathrm{a}} \pm 0.1$ & $0.2^{\mathrm{b}} \pm 0.0$ \\
\hline $22: 0$ & $0.1^{\mathrm{a}} \pm 0.0$ & $0.2^{\mathrm{a}} \pm 0.0$ & $0.5^{\mathrm{a}} \pm 0.1$ & $0.4^{\mathrm{a}} \pm 0.0$ & $1.6^{\mathrm{a}} \pm 0.5$ & $0.1^{\mathrm{b}} \pm 0.0$ \\
\hline SFA & $50.1^{\mathrm{a}} \pm 5.3$ & $61.4^{\mathrm{b}} \pm 2.5$ & $64.9^{\mathrm{a}} \pm 8.1$ & $57.1^{\mathrm{b}} \pm 4.5$ & $59.7^{\mathrm{a}} \pm 9.9$ & $88.8^{\mathrm{b}} \pm 6.5$ \\
\hline $16: 1 n-9$ & $0.4^{\mathrm{a}} \pm 0.1$ & $3.6^{\mathrm{b}} \pm 0.7$ & $0.3^{\mathrm{a}} \pm 0.0$ & $0.8^{\mathrm{b}} \pm 0.1$ & $0.4^{\mathrm{a}} \pm 0.1$ & $0.2^{\mathrm{a}} \pm 0.0$ \\
\hline $16: 1 n-7$ & $9.5^{\mathrm{a}} \pm 0.2$ & $1.6^{\mathrm{b}} \pm 0.3$ & $4.6^{\mathrm{a}} \pm 0.8$ & $5.8^{\mathrm{a}} \pm 0.4$ & $1.0^{\mathrm{a}} \pm 0.1$ & $0.3^{\mathrm{b}} \pm 0.1$ \\
\hline $18: 1 n-9$ & $3.1^{\mathrm{a}} \pm 0.2$ & $3.8^{\mathrm{a}} \pm 0.9$ & $3.4^{\mathrm{a}} \pm 0.2$ & $3.4^{\mathrm{a}} \pm 0.9$ & $3.7^{\mathrm{a}} \pm 0.9$ & $0.6^{\mathrm{b}} \pm 0.1$ \\
\hline $18: 1 n-7$ & $1.9^{\mathrm{a}} \pm 0.2$ & $3.1^{b} \pm 0.2$ & $1.8^{\mathrm{a}} \pm 0.1$ & $2.1^{\mathrm{a}} \pm 0.2$ & $0.7^{\mathrm{a}} \pm 0.2$ & $0.2^{\mathrm{b}} \pm 0.0$ \\
\hline $20: 1 n-11$ & - & $1.0 \pm 0.3$ & $0.5^{\mathrm{a}} \pm 0.1$ & $0.1^{\mathrm{b}} \pm 0.0$ & - & - \\
\hline $20: 1 n-9$ & $5.1^{\mathrm{a}} \pm 1.2$ & $4.2^{\mathrm{a}} \pm 0.1$ & $2.3^{\mathrm{a}} \pm 0.5$ & $1.1^{\mathrm{b}} \pm 0.3$ & $15.4^{\mathrm{a}} \pm 1.5$ & $5.1^{\mathrm{b}} \pm 1.2$ \\
\hline $20: 1 n-7$ & $1.5^{\mathrm{a}} \pm 0.5$ & $1.3^{\mathrm{a}} \pm 0.2$ & $0.7^{\mathrm{a}} \pm 0.1$ & $4.3^{\mathrm{b}} \pm 1.2$ & $0.7^{\mathrm{a}} \pm 0.1$ & $0.2^{\mathrm{b}} \pm 0.0$ \\
\hline MUFA & $21.5^{\mathrm{a}} \pm 1.8$ & $18.6^{\mathrm{b}} \pm 3.5$ & $13.6^{\mathrm{a}} \pm 1.9$ & $17.6^{\mathrm{a}} \pm 2.7$ & $21.9^{\mathrm{a}} \pm 3.1$ & $6.6^{\mathrm{b}} \pm 2.9$ \\
\hline $16: 2$ & $0.4^{\mathrm{a}} \pm 0.1$ & $1.1^{\mathrm{b}} \pm 0.2$ & $0.6^{\mathrm{a}} \pm 0.1$ & $2.5^{\mathrm{b}} \pm 0.5$ & $0.3^{\mathrm{a}} \pm 0.1$ & $0.3^{\mathrm{a}} \pm 0.1$ \\
\hline $16: 3$ & $1.6^{\mathrm{a}} \pm 0.1$ & $0.6^{\mathrm{b}} \pm 0.1$ & $0.7^{\mathrm{a}} \pm 0.1$ & $1.6^{b} \pm 0.3$ & $0.6^{\mathrm{a}} \pm 0.1$ & $0.2^{\mathrm{b}} \pm 0.0$ \\
\hline $16: 4$ & $0.7^{\mathrm{a}} \pm 0.1$ & $1.4^{\mathrm{b}} \pm 0.6$ & $0.6^{\mathrm{a}} \pm 0.0$ & $0.5^{\mathrm{a}} \pm 0.1$ & $3.8^{\mathrm{a}} \pm 0.5$ & $0.1^{\mathrm{b}} \pm 0.0$ \\
\hline $21: 5$ & $0.3^{\mathrm{a}} \pm 0.0$ & $0.5^{\mathrm{a}} \pm 0.1$ & $0.8^{\mathrm{a}} \pm 0.2$ & $0.3^{\mathrm{b}} \pm 0.0$ & $0.9^{\mathrm{a}} \pm 0.4$ & $0.2^{\mathrm{b}} \pm 0.0$ \\
\hline $22: 2$ & $0.8^{\mathrm{a}} \pm 0.2$ & $0.3^{\mathrm{b}} \pm 0.1$ & $1.5^{\mathrm{a}} \pm 0.2$ & $1.3^{\mathrm{a}} \pm 0.4$ & $0.4^{\mathrm{a}} \pm 0.1$ & $0.3^{\mathrm{a}} \pm 0.0$ \\
\hline $18: 2 n-6$ & $1.6^{\mathrm{a}} \pm 0.2$ & $5.8^{\mathrm{b}} \pm 1.1$ & $2.7^{\mathrm{a}} \pm 0.9$ & $4.1^{\mathrm{a}} \pm 1.1$ & $2.1^{\mathrm{a}} \pm 0.9$ & $0.6^{\mathrm{b}} \pm 0.1$ \\
\hline $20: 2 n-6$ & $0.6^{\mathrm{a}} \pm 0.1$ & $0.9^{\mathrm{a}} \pm 0.1$ & $0.9^{\mathrm{a}} \pm 0.1$ & $0.6^{\mathrm{a}} \pm 0.1$ & $0.3^{\mathrm{a}} \pm 0.1$ & $0.1^{\mathrm{a}} \pm 0.0$ \\
\hline $20: 3 n-6$ & $0.7^{\mathrm{a}} \pm 0.1$ & $0.6^{\mathrm{a}} \pm 0.2$ & $0.7^{\mathrm{a}} \pm 0.1$ & $0.5^{\mathrm{a}} \pm 0.1$ & $0.7^{\mathrm{a}} \pm 0.3$ & $0.2^{\mathrm{b}} \pm 0.0$ \\
\hline $20: 4 n-6$ & $2.2^{\mathrm{a}} \pm 0.7$ & $1.5^{\mathrm{a}} \pm 0.2$ & $0.9^{\mathrm{a}} \pm 0.1$ & $1.0^{\mathrm{a}} \pm 0.2$ & $0.4^{\mathrm{a}} \pm 0.0$ & $0.2^{\mathrm{a}} \pm 0.0$ \\
\hline $18: 3 n-3$ & $1.0^{\mathrm{a}} \pm 0.1$ & $0.7^{\mathrm{a}} \pm 0.1$ & $1.4^{\mathrm{a}} \pm 0.5$ & $1.3^{\mathrm{a}} \pm 0.5$ & $1.9^{\mathrm{a}} \pm 0.8$ & $0.5^{\mathrm{b}} \pm 0.1$ \\
\hline $18: 4 n-3$ & - & $1.2 \pm 0.2$ & $2.0^{\mathrm{a}} \pm 0.9$ & $0.5^{\mathrm{b}} \pm 0.1$ & $0.1^{\mathrm{a}} \pm 0.0$ & $0.1^{\mathrm{a}} \pm 0.0$ \\
\hline $20: 3 n-3$ & $0.8^{\mathrm{a}} \pm 0.2$ & $1.0^{\mathrm{a}} \pm 0.4$ & $1.5^{\mathrm{a}} \pm 0.5$ & $0.8^{\mathrm{b}} \pm 0.2$ & $0.3^{\mathrm{a}} \pm 0.1$ & $0.1^{\mathrm{a}} \pm 0.0$ \\
\hline $20: 5 n-3$ & $6.2^{\mathrm{a}} \pm 2.2$ & $0.8^{\mathrm{b}} \pm 0.2$ & $2.4^{\mathrm{a}} \pm 1.2$ & $1.9^{\mathrm{a}} \pm 0.7$ & $4.4^{\mathrm{a}} \pm 0.8$ & $1.1^{\mathrm{b}} \pm 0.3$ \\
\hline $22: 3 n-3$ & $0.7^{\mathrm{a}} \pm 0.1$ & $1.2^{\mathrm{b}} \pm 0.5$ & $1.7^{\mathrm{a}} \pm 0.8$ & $0.8^{\mathrm{a}} \pm 0.1$ & $0.4^{\mathrm{a}} \pm 0.1$ & $0.2^{\mathrm{a}} \pm 0.0$ \\
\hline $22: 5 n-3$ & $0.9^{\mathrm{a}} \pm 0.1$ & $0.9^{\mathrm{a}} \pm 0.3$ & $0.5^{\mathrm{a}} \pm 0.1$ & $0.6^{\mathrm{a}} \pm 0.1$ & $0.4^{\mathrm{a}} \pm 0.0$ & $0.1^{\mathrm{a}} \pm 0.0$ \\
\hline $22: 6 n-3$ & $9.9^{\mathrm{a}} \pm 0.5$ & $1.5^{b} \pm 0.9$ & $2.6^{\mathrm{a}} \pm 0.1$ & $7.0^{\mathrm{b}} \pm 1.6$ & $1.4^{\mathrm{a}} \pm 0.3$ & $0.3^{b} \pm 0.0$ \\
\hline PUFA & $28.4^{\mathrm{a}} \pm 2.6$ & $20.0^{\mathrm{b}} \pm 3.1$ & $21.5^{\mathrm{a}} \pm 1.5$ & $25.3^{\mathrm{b}} \pm 4.8$ & $18.4^{\mathrm{a}} \pm 1.9$ & $4.6^{b} \pm 2.2$ \\
\hline n6 & $5.1^{\mathrm{a}} \pm 0.9$ & $8.8^{\mathrm{b}} \pm 2.1$ & $5.2^{\mathrm{a}} \pm 1.9$ & $6.2^{\mathrm{a}} \pm 2.3$ & $3.5^{\mathrm{a}} \pm 0.9$ & $1.1^{\mathrm{b}} \pm 0.4$ \\
\hline n3 & $19.5^{\mathrm{a}} \pm 4.1$ & $7.3^{b} \pm 0.9$ & $12.1^{\mathrm{a}} \pm 3.3$ & $12.9^{\mathrm{a}} \pm 3.5$ & $8.9^{\mathrm{a}} \pm 2.5$ & $2.4^{\mathrm{b}} \pm 0.9$ \\
\hline
\end{tabular}

Results are mean \pm standard deviation of triplicate analysis $(n=6)$. SAFA: Saturated Fatty Acids; MUFA: Monounsaturated Fatty Acids; PUFA: Polyunsaturated Fatty Acids. Different letters in the same line indicate significant difference by Duncan's test at 5\% level. 
other biochemical components is probably a protection strategy against the loss the structural components of the animal (proteins and lipids).

In this study, we observed that up to $60 \%$ of protein had been utilized after 21 days of food deprivation. The highest loss of protein in F. glaber is recorded in the digestive gland. As recorded in Donax vittatus [27] and Mytilus edulis [7], the mobilization of proteins in bivalves occurs after the depletion of glycogen. Lane [26] has shown that proteins constitute the main source of calories compared to other metabolites (carbohydrates and lipids). Furthermore, Ansell and Sivada [27] pointed out that proteins act as a respiratory substrate in case of food deprivation in bivalves.

Our results indicate that food deprivation led to the decrease of total lipids at the different studied organs in F. glaber. The loss of lipids is greater in the adductor muscle and digestive gland than gonads. This result is most likely due to the mobilization of lipids from the adductor muscle and digestive gland to the gonads to maintain their development. These results are consistent with those obtained by Liu et al., [22] in the mussels $C$. gigas. These authors have shown that during food deprivation, energy reserves are mobilized to ensure the survival of the bivalve and the gonadal development even if spawning is prevented.

Lipids serve as an important endogenous energy reserve in marine invertebrates [28]. The calculation of the relative percentages of neutral and polar lipids in F. glaber shows that neutral lipids dominate lipids of the digestive gland and gonads. However, adductor muscle lipids are predominantly phospholipids. The dominance of neutral lipids in the digestive gland in scallops is related to the role of this organ in the storage of fat reserves as mentioned by several authors [8-10]. In the gonads, the high percentage of neutral lipids seems to be related to the accumulation of lipid reserves at the ovarian compartment and particularly in oocytes. Our results are consistent with those recorded in the bivalve Ensis arcuatus [29]. This observation was also confirmed by 14C labeling in Argopecten irradians concentricus by Barber and Blake [30]. Concerning the adductor muscle, the high percentage of phospholipids seems to be related to the structural role of these lipids in the membrane. The adductor muscle of F. glaber is not a lipid storage organ. Same results were recorded for the scallops A. irradians concentricus and A. purpuratus [30,31] and the oyster $C$. gigas [3].

The present study evaluated the effect of starvation on the lipid class distribution in the polar and neutral lipids of F. glaber. Qualitatively, we note that at the beginning of the experiment, the polar lipid fraction was dominated by PC class in all studied organs. This dominance of the
PC class has been reported in some bivalve species $[32,33]$. On neutral lipids, cholesterol was the dominant fraction in the three analyzed organs; however, gonads show a substantial amount of this lipid class. In fact, it has been reported that sterols and sterol esters represent the main components of the gonads of marine bivalves $[34,35]$.

The noteworthy recorded effect of the starvation trial was the increase of the amount of PE against a strong decline of MDG, TAG and PS classes in gonads. This observation has led us to hypothesize that $F$. glaber is capable of remodeling endogenous lipid classes by synthesizing the PE de novo via CDP-DAG pathway. The elevation of PE in starved F. glaber is justified by the role of this amino derivative in the reinforcement and structuring of the membrane in order to avoid the organ deterioration. The structural and functional roles of the PE have been outlined in the male gonads of Pecten maximus by Soudant et al., [36].

Concerning the neutral lipids, starvation induced mainly the increase of FFA class in the adductor muscle. This elevation is probably due to catabolic reactions of MDG and TAG required for the energy production. Similar findings were observed in Mytilus galloprovincialis [37]. Furthermore, Caers et al., [38] have associated the presence of FFA in C. gigas and Tapes phillippinarum to the hydrolysis of acylglycerols. This was also confirmed by Huca et al., [39] in the bivalve Diplodon delodontus by radioactive labeling.

It is admitted that the TAG fraction is known as the major reserve of lipids and an indicator of the nutritional state in some bivalve species [40,41]. Hence, the effects of starvation on the fatty acid profiles of the TAG class of different organs of $F$. glaber were investigated.

Starved specimens had relatively greater amounts of SFA and mainly the C18:0 in digestive gland and both C18:0 and C16:0 in muscle. Antagonist tendencies were observed in gonads. Such a result is most likely due to the de novo synthesis of $\mathrm{C} 16: 0$ and $\mathrm{C} 18: 0$ fatty acids to support the increased energy requirements as demonstrated by labeled ${ }^{14} \mathrm{C}$-acyl groups in the stressed oyster C. virginica by Chu and Greaves [42].

In the $F$. glaber storage organs (digestive gland and adductor muscle), the severe declines of the n-3 PUFAs (mainly the EPA and DHA after a 3 weeks starvation period) point out the role of TAG which is considered as a PUFA reservoir that could be used as the need arises as mentioned by Pernet et al., [40]. Furthermore, we recorded an increase of the percentages of the PUFAs group in the gonads of the starved specimens. It is therefore, likely, that the PUFA groups stored in the TAG fractions of the digestive gland and the adductor muscle were transferred to the developing gonads during the 
food shortage trial as mentioned before. Many authors have demonstrated that, depending on their environment, bivalves may support gametogenesis using recently ingested food, stored reserves or a combination of the two [43].

In this study we have recorded among the gonad's PUFA group, an increase of the DHA and maintain of the ARA. The increasing amount of DHA is attributed to its major role in the maintenance of the structural and functional integrity of cell membranes [44]. The retention of the ARA reflects the importance of this fatty acid as a precursor of prostaglandins. The latter is involved in reproduction and immune response of different mollusk species as revealed by Hurtado et al., [45]. Those finding concur with other studies in which a selective retention of the 20:4n-6 was reported in starved M. galloprovincialis [25].

\section{REFERENCES}

[1] C. Ruiz, M. Abad, F. Sedano, L. O. Garcia-Martin and J. L. Sanchez-Lopez, "Influence of Seasonal Environmental Changes on the Gamete Production and Biochemical Composition of Crassostrea gigas (Thunberg) in Suspended Culture in El Grove, Galicia, Spain," Journal of Experimental Marine Biology and Ecology, Vol. 155, No. 2, 1992, pp. 249-262. doi:10.1016/0022-0981(92)90066-J

[2] F. Ruano, P. Ramos, M. Quaresma, N. M. Bandarra and I. Pereira Da Fonseca, "Evolution of Fatty Acid Profile and Condition Index in Mollusc Bivalves Submitted to Different Depuration Periods," Revista Portuguesa da Ciências Veterinárias, Vol. 111, No. 581-582, 2012, pp. 7584.

[3] C. Berthelin, K. Kellner and M. Mathieu, "Storage Metabolism in the Pacific Oyster (Crassostrea gigas) in relation to Summer Mortalities and Reproductive Cycle (West Coast of France)," Comparative Biochemistry and Physiology Part B, Vol. 125, No. 3, 2000, pp. 359-369. doi:10.1016/S0305-0491(99)00187-X

[4] C. J. Lodeiros, J. J. Rengel, H. E. Guderley, O. Nusetti and J. H. Himmelman, "Biochemical Composition and Energy Allocation in the Tropical Scallop Lyropecten (Nodipecten) nodosus during the Months Leading up to and Following the Development of Gonads," Aquaculture, Vol. 199, No. 1-2, 2001, pp. 63-72. doi:10.1016/S0044-8486(01)00505-1

[5] I. Laing and A. R. Child, "Comparative Tolerance of Small Juvenile Palourdes (Tapes decussatus L.) and Manila clams (Tapes philippinarum Adams \& Reeve) to Low Temperature," Journal of Experimental Marine Biology and Ecology, Vol. 195, No. 2, 1996, pp. 267-285. doi:10.1016/0022-0981(95)00097-6

[6] A. Pérez-Camacho, M. Albentosa, M. J. Fernandez-Reiriz and U. Labarta, "Effect of Microalgal and Inert (Cornmeal and Cornstarch) Diets on Growth Performance and Biochemical Composition of Ruditapes decussatus Seed," Aquaculture, Vol. 160, No. 1-2, 1998, pp. 89-102.

\section{doi:10.1016/S0044-8486(97)00232-9}

[7] J. Epp, V. M. Bricelj and R. E. Malouf, "Seasonal Partitioning and Utilization of Energy Reserves in Two Age Classes of the Bay Scallop Argopecten irradians (Lamarck)," Journal of Experimental Marine Biology and Ecology," Vol. 121, No. 2, 1988, pp. 113-136. doi:10.1016/0022-0981(88)90250-X

[8] G. E. Napolitano and R. G. Ackman, "Anatomical Distributions and Temporal Variations of Lipid Classes in Sea Scallops Placopecten magellanicus (Gmelin) from Georges Bank (Nova Scotia)," Comparative Biochemistry and Physiology Part B, Vol. 103, No. 3, 1992, pp. 645650. doi:10.1016/0305-0491(92)90384-4

[9] G. Le Pennec, M. Le Pennec and P. G. Beninger, "Seasonal Digestive Gland Dynamics of the Scallop Pecten maximus in the Bay of Brest (France)," Journal of Marine Biology Association United Kingdom, Vol. 81, No. 4, 2001, pp. 663-671.

[10] A. J. Pazos, J. L. Sanchez, G. Roman, M. L. Pérez-Prallé and M. Abad, "Seasonal Changes in Lipid Classes and Fatty Acid Composition in the Digestive Gland of Pecten maximus," Comparative Biochemistry and Physiology Part B, Vol. 134, No. 2, 2003, pp. 367-380. doi:10.1016/S1096-4959(02)00286-5

[11] W. Fischer, M. L. Bauchot and M. Schneider, "Méditerranée et Mer Noire (Fishing Area 37). Fiches FAO d'Identification des Espèces pour le Besoin de la Pêche," Vol. 1-2. FAO, Rome, 1987.

http://www.fao.org/docrep/009/x0170f/x0170f00.htm

[12] K. Telahigue, I. Chetoui, I. Rabeh, M. S. Romdhane and M. El Cafsi, "Comparative Fatty Acid Profiles in Edible Parts of Wild Scallops from the Tunisian Coast," Food Chemistry, Vol. 122, No. 3, 2010, pp. 744-746. doi:10.1016/j.foodchem.2010.03.047

[13] M. Albentosa, M. J. Fernandez-Reiriz, U. Labarta and A. Perez-Camacho, "Response of Two Species of Clams, Ruditapes decussatus and Venerupis pullastra, to Starvation: Physiological and Biochemical Parameters," Comparative Biochemistry and Physiology Part B, Vol. 146, No. 2, 2007, pp. 241-249. doi:10.1016/j.cbpb.2006.10.109

[14] J. Folch, M. Lees and G. A. Sloane-Stanley, "A Simple Method for the Isolation and Purification of Total Lipids from Animal Tissues," Journal of Biological Chemistry, Vol. 226, No.1, 1957, pp. 497-509.

[15] M. Dubois, K. A. Gilles, J. K. Hamilton, P. A. Rebers and F. Smith, "Colorimetric Method for Determination of Sugars and Related Substances," Analytical Chemistry, Vol. 28, No. 3, 1956, pp. 350-356. doi: $10.1021 / \mathrm{ac} 60111 \mathrm{a} 017$

[16] O. H. Lowry, N. J. Rosebrough, A. L. Farr and R. J. Randall, "Protein Measurement with the Folin Phenol Reagent," The Journal of Biological Chemistry, Vol. 193, No. 1, 1951, pp. 265-275.

[17] R. E. Olsen and R. J. Henderson, "The Rapid Analysis of Neutral and Polar Marine Lipids Using Double-Development HPTLC and Scanning Densitometry," Journal of Experimental Marine Biology and Ecology, Vol. 129, No. 
2, 1989, pp. 189-197. doi:10.1016/0022-0981(89)90056-7

[18] G. Cecchi, S. Basini and C. Castano, "Méthanolyse Rapide des Huiles en Solvant," Revue Française des Corps Gras, Vol. 32, No. 4, 1985, pp. 163-164.

[19] H. Pieters, J. H. Klutymans, W. Zurburg and D. I. Zandee, "The Influence of Seasonal Changes on Energy Metabolism in Mytilus edulus (L.). 1. Growth Rate and Biochemical Composition in Relation to Environmental Parameters and Spawning," In: E. Naylor and R. Hartnoll, Eds., Cyclic Phenomena in Marine Plants and Animals, Pergamon Press, Oxford, 1979, pp. 285-292.

[20] X. Q. Su, K. N. Antonas and D. Li, "Comparison of n-3 Polyunsaturated Fatty Acid Contents of Wild and Cultured Australian Abalone," International Journal of Food Sciences and Nutrition, Vol. 55, No. 2, 2004, pp. 149-154. doi:10.1080/09637480410001666469

[21] T. H. Carefoot, P. Y. Qian, B. E. Taylor, T. West and J. Osborne, "Effect of Starvation on Energy Reserves and Metabolism in the Northern Abalone, Haliotis kamtschatkana," Aquaculture, Vol. 118, No. 3-4, 1993, pp. 315-325. doi:10.1016/0044-8486(93)90466-C

[22] W. Liu, Q. Li, F. Gao and L. Kong, "Effect of Starvation on Biochemical Composition and Gametogenesis in the Pacific Oyster Crassostrea gigas," Fisheries Science, Vol. 76, No. 5, 2010, pp. 737-745. doi:10.1007/s12562-010-0274-y

[23] A. C. Giese, "A New Approach to the Biochemical Composition of the Mollusc Body," Oceanogrraphy and Marine Biology Annual Review, Vol. 7, 1969, pp. 175-229.

[24] J. J. Beukema and W. De Bruin, "Seasonal Changes in Dry Weight and Chemical Composition of the Soft Parts of the Tellinid Bivalve Macoma balthica in the Dutch Wadden Sea," Netherlands Journal of Sea Research, Vol. 11, No. 1, 1977, pp. 42-55. doi:10.1016/0077-7579(77)90020-5

[25] M. Pirini, M. P. Manuzzi, A. Pagliarani, F. Trombetti, A. R. Borgatti and V. Ventrella, "Changes in Fatty Acid Composition of Mytilus galloprovincialis (Lmk) Fed on Microalgal and Wheat Germ Diets," Comparative Biochemistry and Physiology Part B, Vol. 147, No. 4, 2007, pp. 616-626. doi:10.1016/j.cbpb.2007.04.003

[26] J. M. Lane, "Allometric and Biochemical Studies on Starved and Unstarved Clams, Rangia cuneata (Sowerby, 1831)," Journal of Experimental Marine Biology and Ecology, Vol. 95, No. 2, 1986, pp.131-143. doi:10.1016/0022-0981(86)90197-8

[27] A. D. Ansell and P. Sivadas, "Some Effects of Temperature and Starvation on the Bivalve Donax virtatus (Da Costa) in Experimental Laboratory Populations," Journal of Experimental Marine Biology and Ecology, Vol. 13, No. 3, 1973, pp. 229-262. doi:10.1016/0022-0981(73)90069-5

[28] K. C. Stuck, S. A. Watts and S. Y. Wang, "Biochemical Responses during Starvation and Subsequent Recovery in Postlarval Pacific White Shrimp, Penaeus vannamei," Marine Biology, Vol. 125, No. 1, 1996, pp. 33-45. doi:10.1007/BF00350758
[29] S. Darriba, F. San Juan and A. Guerra, "Energy Storage and Utilization in Relation to the Reproductive Cycle in the Razor Clam Ensis arcuatus (Jefterys 1865)," ICES Journal of Marine Science, Vol. 62, No. 5, 2005, pp. 886896. doi:10.1016/j.icesjms.2005.02.010

[30] B. J. Barber and N. J. Blake, "Energy Storage and Utilization in Relation to Gametogenesis in Argopecten irradians concentricus (Say)," Journal of Experimental Marine Biology and Ecology, Vol. 52, No. 2-3, 1981, pp. 121-134. doi:10.1016/0022-0981(81)90031-9

[31] M. Caers, P. Coutteau, P. Sorgeloos and G. Gajardo, "Impact of Algal Diets and Emulsions on the Fatty Acid Composition and Content of Selected Tissues of Adult Broodstock of the Chilean Scallop Argopecten purpuratus (Lamarck, 1819)," Aquaculture, Vol. 217, No. 1-4, 2003, pp. 437-452. doi:10.1016/S0044-8486(02)00144-8

[32] P. Soudant, J. Moal, Y. Marty and J. F. Samain, "Composition of Polar Lipid Classes in Male Gonads of Pecten maximus (L.). Effect of Nutrition," Journal of Experimental Marine Biology and Ecology, Vol. 215, No. 1, 1997, pp. 103-114. doi:10.1016/S0022-0981(97)00028-2

[33] N. V. Zhukova, "Lipid Classes and Fatty Acid Composition of the Tropical Nudibranch Mollusks Chromodoris sp. and Phyllidia coelestis," Lipids, Vol. 42, No. 12, 2007, pp. 1169-1175. doi:10.1007/s11745-007-3123-8

[34] J. R. Pollero, M. E. Re and R. Brenner, "Seasonal Changes of the Lipids of the Mollusc Chlamys tehuelcha," Comparative Biochemistry and Physiology Part A, Vol. 64, No. 2, 1979, pp. 257-263. doi:10.1016/0300-9629(79)90658-3

[35] I. Y. Ahn, K. W. Cho, K. S. Choi, Y. Seo and J. Shin, "Lipid Content and Composition of the Antarctic Lamellibranch, Laternula elliptica (King and Broderip) (Anomalodesmata: Laternulidae), in King George Island during an Austral Summer," Polar Biology, Vol. 23, No. 1, 2000, pp. 24-33. doi:10.1007/s003000050004

[36] P. Soudant, Y. Marty, J. Moal, R. Robert, C. Quéré, J. R. Le Coz and J. F. Samain, "Effect of Food Fatty Acid and Sterol Quality on Pecten maximus Gonad Composition and Reproduction Process," Aquaculture, Vol. 143, No. 3-4, 1996, pp. 361-378. doi:10.1016/0044-8486(96)01276-8

[37] L. Freites, M. J. Fernandez-Reiriz and U. Labarta, "Fatty Acid Profiles of Mytilus galloprovincialis (Lamarck) Mussel of Subtidal and Rocky Shore Origin," Comparative Biochemistry and Physiology Part B, Vol. 132, No. 2, 2002, pp. 453-461. doi:10.1016/S1096-4959(02)00057-X

[38] M. Caers, P. Coutteau and P. Sorgeloos, "Impact of Starvation and of Feeding Algal and Artificial Diets on the Lipid Content and Composition of Juvenile Oysters (Crassostrea gigas) and Clams (Tapes philippinarum)," Marine Biology, Vol. 136, No. 5, 2000, pp. 891-899. doi:10.1007/s002270000295

[39] G. A. Huca, R. J. Pollero and R. R. Brenner, "Digestion and Distribution of Tripalmitoylglycerol in Diplodon delodontus (Mollusca, Bivalvia)," Biological Bulletin, Vol. 167, No. 3, 1984, pp. 698-703. doi:10.2307/1541420

[40] F. Pernet, S. Gauthier-Clerc and E. Mayrand, "Change in 
Lipid Composition in Eastern Oyster (Crassostrea virginica Gmelin) Exposed to Constant or Fluctuating Temperature Regimes," Comparative Biochemistry and Physiology Part B, Vol. 147, No. 3, 2007, pp. 557-565.

doi:10.1016/j.cbpb.2007.03.009

[41] E. Prato, A. Danieli, M. Maffia and F. Biandolino, "Lipid and Fatty Acid Compositions of Mytilus galloprovincialis Cultured in the Mar Grande of Taranto (Southern Italy): Feeding Strategies and Trophic Relationships," Zoological Studies, Vol. 49, No. 2, 2010, pp. 211-219.

[42] F. L. E. Chu and J. Greaves, "Metabolism of Palmitic, Linoleic and Linolenic Acids in Adult Oysters, Crassostrea virginica," Marine Biology, Vol. 110, No. 2, 1991, pp. 229-236. doi:10.1007/BF01313708

[43] B. J. Barber and N. J. Blake, "Reproductive Physiology,"
In: S. E. Shumway and G. J. Parsons, Eds., Scallops: Biology, Ecology and Aquaculture, Elsevier, Amsterdam, 2006, pp. 357-416. doi:10.1016/S0167-9309(06)80033-5

[44] F. Delaunay, Y. Marty, J. Moal and J. F. Samain, "The Effect of Monospecific Algal Diets on Growth and Fatty Acid Composition of Pecten maximus (L.) Larvae," Journal of Experimental Marine Biology and Ecology, Vol. 173, No. 2, 1993, pp. 163-179. doi:10.1016/0022-0981(93)90051-O

[45] M. A. Hurtado, M. Reza, A. M. Ibarra, M. Wille, P. Sorgeloos, P. Soudant and E. Palacios, "Arachidonic Acid (20:4n-6) Effect on Reproduction, Immunology, and Prostaglandin E2 Levels in Crassostrea corteziensis (Hertlein, 1951)," Aquaculture, Vol. 294, No. 3-4, 2009, pp. 300-305. doi:10.1016/j.aquaculture.2009.06.009 